\title{
Development of forest carbon stock and wood production in the Czech Republic until 2060
}

\author{
Emil CiEnCIAlA $^{1 *}$, Zuzana EXNERovÁ ${ }^{1}$, Mart-Jan SCHELHAAs $^{2}$ \\ ${ }^{1}$ Institute of Forest Ecosystem Research, 25401 Jílové u Prahy 1544, Czech Republic \\ ${ }^{2}$ Alterra Wageningen UR, Wageningen, The Netherlands
}

(Received 31 October 2007; accepted 6 June 2008)

\begin{abstract}
-
- This study describes the scenarios of likely development of carbon pools in managed forest ecosystems of the Czech Republic. The analysis was based on a matrix scenario model (EFISCEN), adopting a novel parameterization based on forest stand site types and forest typology. The model was constrained by practical management rules as prescribed by the Czech Forestry Act and used to assess production potential for the next five decades under three management and three climate scenarios. The analysis provided data on carbon pool development, including both tree biomass and soil compartments.

- For the tested scenarios of sustainable forest management (wood removals not exceeding increment) the model indicated a slight increase of soil carbon pool. For the possibly largest removals (maximum sustainable felling scenario), soil carbon stabilized within two or three decades reaching a mean value of about $8.1 \mathrm{~kg} / \mathrm{m}^{2}$ for. At the same time, the mean carbon stock held in biomass reached about $10.2 \mathrm{~kg} / \mathrm{m}^{2}$ including belowground parts. No decline of soil carbon was observed for any of the tested scenarios.

- We conclude that it is reasonable to assume that soil carbon is not a source of carbon under the current management constraints as implemented in the Czech forestry practice.
\end{abstract}

forest ecosystem / forest management / soil / climate change / model prediction

Résumé - Évolution du stock de carbone forestier et de la production de bois en République Tchèque jusqu'en 2060.

- Cette étude décrit les scénarios des évolutions probables des pools de carbone dans les écosystèmes forestiers aménagés de la République Tchèque. L'analyse a été basée sur un modèle de scénario matriciel (EFISCEN), en adoptant une paramétrisation originale basée sur des types de station de peuplements forestiers et sur une typologie forestière. Le modèle était limité par des règles de gestion pratiques comme celles qui sont prescrites par les lois forestières tchèques et était utilisé pour estimer le potentiel de production pour les cinq prochaines décades sous trois types de gestion et scénarios climatiques. L'analyse fournit des données sur l'évolution du pool de carbone, en incluant la biomasse de l'arbre et les compartiments du sol.

- Pour les scénarios de gestion forestière durable (enlèvement de bois n'excédant pas l'accroissement) testés, le modèle indique un léger accroissement du pool de carbone du sol. Pour de possibles plus grands enlèvements (scénario d'abattage maximum en gestion durable), le carbone du sol se stabilise dans les deux ou trois décades atteignant une valeur moyenne de $8,1 \mathrm{~kg} / \mathrm{m}^{2}$ for. Dans le même temps, le stock moyen de carbone contenu dans la biomasse atteignait environ $10,2 \mathrm{~kg} / \mathrm{m}^{2}$ en incluant les parties souterraines. Il n'a pas été observé de diminution du carbone du sol pour aucun des scénarios testés.

- Nous concluons qu'il est raisonnable de supposer que le carbone du sol n'est pas une source de carbone qui est influencée par les contraintes de la gestion courante mise en œuvre en pratique dans la foresterie tchèque.

écosystème forestier / gestion / sol / changement climatique / modèle de prédiction

\section{INTRODUCTION}

Forestry is characterized by a long term production cycle, which requires adequate planning of forest management measures. Hence, insight into the future production potential and growth of forest is of very vital importance to forestry. The strategic importance of long-term planning in forestry is enhanced by changes in climatic and environmental conditions, which affect growth performance and stability of current forest ecosystems. Forest resources in broader terms mean not just a production of wood, but provide also other functions to society. In recent years, specifically the ability of forest ecosystems

*Corresponding author: Emil.Cienciala@ifer.cz to sequester carbon and mitigate climate change has attracted attention of environmental research and policy agendas. Under the Climate Convention (UNFCCC - United Nations' Convention on Climate Change) and its Kyoto protocol, forests, together with land-use and change form one sector (LULUCF) of the national emission inventories. Similarly as for other sectors, the UNFCCC requires assessment and reporting of emissions by sources and sinks, which becomes specifically challenging with respect to changes in forest carbon pools (IPCC, 2003). In Central Europe, these are mainly affected by forest management, which represents a decisive driver of forest carbon dynamics in managed forest of temperate Europe. Therefore, scenario projections of future management can form an 
important complement to the UNFCCC reporting by providing insight into future development of carbon budget. Secondly, the model analysis may be used to comply with the reporting requirements under the Kyoto protocol, providing analytical evidence needed for reporting emissions due to ecosystem carbon stock changes for the obligatory (Art. 3.3) and voluntary (Art. 3.4) activities, such as forest management.

Here, we study the likely development of forest resources of the Czech Republic in terms of production and carbon stock changes in tree biomass and soil. We apply a wood-demand driven modeling tool EFISCEN, which includes the soil component via the YASSO soil model (Liski et al., 2005). EFISCEN simulates the development of forest resources and actual supply based on the current state of the forests, growth, assumptions on required felling level and prescribed management regime. We test several scenarios of likely management strategies, considering both current and changing climate conditions. The model parameterization utilizes the actual data on forest woody biomass in the country based on the data from forest management plans, providing growing stock for tree species and age class. Harvest demand is initiated from the known, reported recent harvest levels for broadleaved and deciduous trees (MA, 2001; 2006). Additionally, EFISCEN as adapted here for the conditions of the Czech Republic includes constraints of actual forest management as prescribed in the Czech Forestry Act. Also specific to this country application is the parameterization of growth performance, which was derived with the help of the local growth and yield model (Cerny, 2005; Schelhaas et al., 2004). The data on forest resources were prepared on the basis of local typological characterization of forest stands, which permitted a matching parameterization of growth performance for major tree species as well as the application of practical management routines. This is in contrast with earlier studies, where data were usually prepared based on administrative units rather than on growth conditions (e.g., Nabuurs et al., 2002; Thürig and Schelhaas, 2006).

The key aim of this study was to quantify the development of forest carbon stock held in biomass and soil under a set of likely management and climate scenarios in the country. All imposed management scenarios comply with the basic constraint of sustainable forest management, i.e., the overall removal of woody biomass is always smaller than the woody increment during the simulated period. The analyzed time period stretches until 2060.

\section{MATERIAL AND METHODS}

\subsection{Model description}

The EFISCEN model (Nabuurs et al., 2001; Pussinen et al., 2001; Sallnas, 1990; Schelhaas et al., 2006) is a matrix-based model specifically suitable for regional or country level predictions. We used the model version 2.2 as described in Pussinen et al. (2001). The model simulates the development of the forest resources in terms of growing stock, area, tree species and age class distribution in time steps of five years. The basic input data required for EFISCEN are data on growing stock and areas categorized by a user-specified set of classifiers (such as tree species, ownership classes, geographical regions) and age classes. The model is a pure forest resource model, not taking into account economic principles, such as development in price and regional or global wood demand and supply. As an input, the model needs the required amounts of fellings. The model quantifies the degree to which this required level can be met by the resource, given management constraints as defined by the user.

The soil module YASSO contained in EFISCEN calculates the amount of carbon in soil. YASSO was developed to model soil carbon stock in mineral soils of managed forests (Liski et al., 2005). It has been previously used in numerous studies, either as a standalone model (e.g., Palosuo et al., 2005; Peltoniemi et al., 2006) or as a build-in module within other models (e.g., Kaipainen et al., 2004). The model calculates the initial soil carbon content from the litter input of the first time period. The litter input originates from trees only. The sub-module consists of three litter compartments describing physical fractionation of litter (stem litter, branch and coarse root litter, and foliage and fine root litter) and of five compartments describing microbiological decomposition in soil (soluble compounds, holocellulose, lignin, and two pools of humus compounds). The litter compartments have specific fractionation rates (ai) and similarly, soil compartments have specific decomposition rates (ki). These rates determine fractions that are removed from the compartments each year. Carbon removed from litter is transferred to soil compartments driven by the chemical composition of the litter (ci). A part of carbon removed from the soil compartments (pi) is transferred to the subsequent compartments and the rest leaves the system. The coefficients ai, ki, ci and pi applied in this model application were given in the EFISCEN manual (Pussinen et al., 2001).

The sum of carbon in individual compartments gives the total soil carbon stock, representing both organic (litter and humus) and mineral soil horizons.

\subsection{Model set-up}

Forestry in the Czech Republic is determined by a large heterogeneity of growth conditions, which are primarily determined by elevation and soil types. This is reflected by the local system of forest typology (Pliva, 1991; Pliva and Zlabek, 1986), which is the basis of practical forest management differentiating specific sets of management stands and accordingly prescribed management regimes. The management sets of stands, basic units of general planning, are identified by two-digit numbers. The first one identifies altitudinal and/or climatic vegetation zone, with larger number representing a higher altitude. The second number determines the site category. Here we used area and volume data for the 26 most important management sets of stands in the country including both coniferous and broadleaved trees (identification numbers 1, 2, 13, 19, 21, 23, 25, 27, 29, 31, 35, 39, 41, $43,45,47,51,53,55,57,59,71,73,75,77,79$ in the Czech classification system). The selected sets of stands for this analysis jointly cover $77.9 \%$ of the forest area and $81.3 \%$ of the growing stock in this country (data as of 2000). For the total area to be applicable for the whole country, it was necessary to apply an expansion factor of 1.28 to obtain country-level data on areas and similarly 1.22 to expand data based on growing stock. Note that the growing stock data were defined as merchantable stem and/or branch volume under bark, with minimum diameter of $7 \mathrm{~cm}$.

The source data come from the database of forest management plans that is administered by the Forest Management Institute (FMI), Brandys n. Labem, Czech Republic. The data available for different tree species were aggregated by the four main tree species used in 

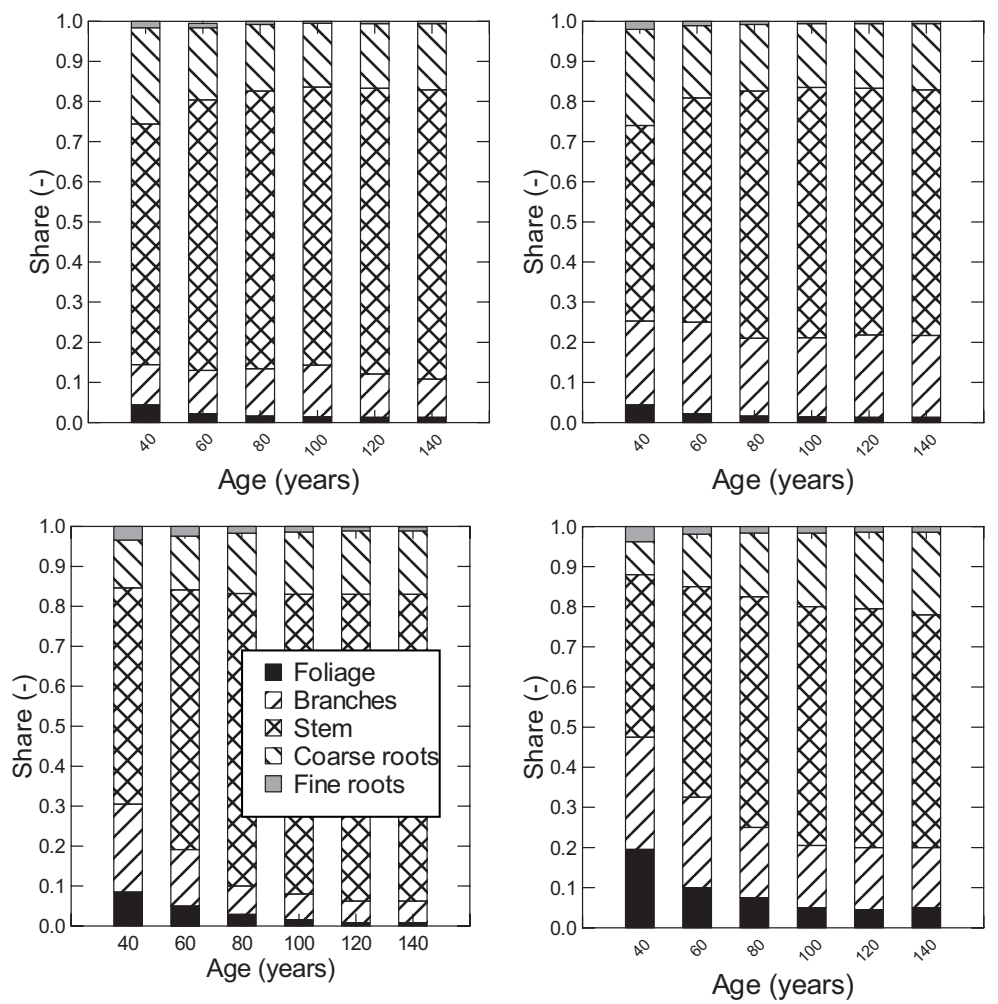

Figure 1. The applied coefficients of biomass distribution values for the main tree species (beech - upper left, oak - upper right, pine - bottom left, spruce - bottom right) according to stand age and individual biomass components.

forestry in this country, namely species are beech (Fagus sylvatica and other deciduous species), oak (Qercus robur, Q. petraea and other oak species), pine (Pinus sylvestris and other pine species, and Larix decidua) and spruce (Picea abies and other coniferous species).

All data used for the model runs are available from the authors on request. The general information on forests and forest conditions can be found in the annual reports on the Czech forestry issued by the Ministry of Agriculture and the Forest Management Institute, Brandys n. Labem (http://www.uhul.cz/zelenazprava).

\subsection{Increment}

The national growth model SILVISIM (Cerny, 2005) was applied to compute current increment for all available combinations of site unit, species and age class. SILVISIM estimates increment from input data including mean stand height, mean stand diameter, species and standing volume. These data were calculated from the national database of forest management plans of Forest Management Institute, Brandys $n$. Labem. The estimated increment was then approximated by a growth function that covered the whole range of age classes. The function had a form of

$$
C I=b \times H^{\left(\frac{a}{H}\right)^{\frac{1}{c}}-1} / c
$$

where $a, b, c$ are fitted parameters and $\mathrm{H}$ is stand height in a functional form of

$$
H=a \times\left(1-\exp ^{-b \times A g e}\right)^{\frac{1}{c}}
$$

where Age is the input variable. The approximated functions were then used as input into EFISCEN. The species-specific current increment was based on the SILVISIM growth model. The calibration data for the four major species in the Czech Republic were available at the level of management sets of stands, species and age classes.

\subsection{Conversion of merchantable volume to carbon stock}

Biomass carbon content was estimated by converting merchantable wood volume to biomass, adopting expansion factors and converting total biomass to carbon. Total aboveground wood volume was converted to dry mass using wood densities of $0.58,0.58,0.42$ and $0.40 \mathrm{t} / \mathrm{m}^{3}$ for beech, oak, pine and spruce, respectively (IPCC, 2003). Since the source volume data were available as underbark, the stem-bark component was accounted for using a factor of 1.15 for oaks and 1.10 for all other tree species, according to common practice in the Czech forestry. The expansion of stem wood biomass to individual biomass components (stem, branches, coarse and fine roots and foliage) was based on published studies on tree allometry applicable to temperate Europe, including beech (Cienciala et al., 2005), pine (Cienciala et al., 2006), oak (Cienciala et al., 2008a) and spruce (Wirth et al., 2004). The applied coefficients of biomass distribution for individual tree components are shown in Figure 1.

Each year a proportion of the individual biomass components of a tree dies, resulting in litter production. To quantify this, biomass turnover rates are required. The lifespan for needle turnover were set to be 5 years for coniferous $\left(0.2 \mathrm{y}^{-1}\right.$ for spruce and pine; Muukonen, 
Table I. Management units: set of stands (MU), felling age (FA), regeneration period (RP), for the major tree species as implemented in the model runs.

\begin{tabular}{|c|c|c|c|c|c|c|c|c|c|c|c|}
\hline MU & Species & FA & RP & MU & Species & FA & RP & MU & Species & FA & $\overline{\mathrm{RP}}$ \\
\hline 1 & Beech & - & - & 31 & Beech & 130 & 30 & 51 & Pine & 120 & 30 \\
\hline 1 & Oak & - & - & 31 & Oak & 130 & 30 & 51 & Spruce & 120 & 30 \\
\hline 1 & Pine & - & - & 31 & Pine & 120 & 30 & 53 & Beech & 140 & 40 \\
\hline 1 & Spruce & - & - & 35 & Beech & 130 & 30 & 53 & Pine & 120 & 30 \\
\hline 2 & Beech & - & - & 35 & Oak & 130 & 30 & 53 & Spruce & 110 & 30 \\
\hline 2 & Spruce & - & - & 35 & Pine & 110 & 20 & 55 & Beech & 130 & 30 \\
\hline 13 & Beech & - & - & 39 & Oak & - & - & 55 & Spruce & 110 & 30 \\
\hline 13 & Oak & - & - & 39 & Pine & 120 & 30 & 57 & Beech & 130 & 40 \\
\hline 13 & Pine & 120 & 20 & 39 & Spruce & 110 & 30 & 57 & Pine & 110 & 20 \\
\hline 13 & Spruce & 110 & 20 & 41 & Beech & 130 & 40 & 57 & Spruce & 110 & 30 \\
\hline 19 & Oak & 130 & 20 & 41 & Oak & - & - & 59 & Oak & - & - \\
\hline 19 & Spruce & 100 & 20 & 41 & Pine & 120 & 30 & 59 & Pine & 120 & 30 \\
\hline 21 & Beech & - & - & 41 & Spruce & 110 & 30 & 59 & Spruce & 100 & 30 \\
\hline 21 & Oak & 130 & 20 & 43 & Beech & 130 & 30 & 71 & Beech & - & - \\
\hline 21 & Pine & 120 & 20 & 43 & Oak & - & - & 71 & Pine & - & - \\
\hline 23 & Beech & 130 & 30 & 43 & Pine & 110 & 20 & 71 & Spruce & 140 & 40 \\
\hline 23 & Oak & 130 & 30 & 43 & Spruce & 110 & 30 & 73 & Beech & - & - \\
\hline 23 & Pine & 110 & 20 & 45 & Beech & 130 & 30 & 73 & Pine & 130 & 40 \\
\hline 25 & Beech & - & - & 45 & Oak & 130 & 30 & 73 & Spruce & 130 & 40 \\
\hline 25 & Oak & 160 & 20 & 45 & Pine & 100 & 20 & 75 & Beech & - & - \\
\hline 25 & Pine & 110 & 20 & 45 & Spruce & 100 & 30 & 75 & Spruce & 130 & 30 \\
\hline 27 & Beech & - & - & 47 & Beech & 130 & 30 & 77 & Beech & - & - \\
\hline 27 & Oak & 130 & 20 & 47 & Oak & 140 & 30 & 77 & Pine & 130 & 40 \\
\hline 27 & Pine & 120 & 20 & 47 & Pine & 110 & 30 & 77 & Spruce & 130 & 30 \\
\hline 27 & Spruce & 90 & 20 & 47 & Spruce & 110 & 30 & 79 & Pine & 120 & 40 \\
\hline 29 & Spruce & 90 & 20 & 51 & Beech & 140 & 30 & 79 & Spruce & 120 & 40 \\
\hline
\end{tabular}

Table II. Probability table for implementation of final felling that respect the prescribed felling age (FA) and regeneration period.

\begin{tabular}{lccccccrr}
\hline Regeneration period & & \multicolumn{5}{c}{ Probabilities (-) } \\
\hline & FA-20 & FA-15 & FA-10 & FA-5 & FA & FA+5 & FA+10 & FA+15 \\
20 years & & & 0.25 & 0.33 & 0.50 & 1.00 & \\
30 years & & 0.17 & 0.20 & 0.25 & 0.33 & 0.50 & 1.00 \\
40 years & 0.13 & 0.14 & 0.17 & 0.20 & 0.25 & 0.33 & 0.50 & 1.00 \\
\hline
\end{tabular}

2005; Muukonen and Lehtonen, 2006), while leaves were replaced every year $\left(1 \mathrm{y}^{-1}\right.$ for beech and oak). The turnover rates for stem ( $0.0087 \mathrm{y}^{-1}$ for deciduous and $0.0043 \mathrm{y}^{-1}$ for coniferous), fine roots $\left(0.868 \mathrm{y}^{-1}\right.$ for all species $)$ and coarse roots and branches $\left(0.025 \mathrm{y}^{-1}\right.$ for deciduous and $0.027 \mathrm{y}^{-1}$ for coniferous) were taken from earlier studies (Schelhaas et al., 2006).

\subsection{Implementation of management constraints}

The management regime in the EFISCEN model is based as closely as possible on the management rules as given by the Czech Forest Act. These rules are used in the Czech forest management practice and prescribe (i) felling age, (ii) regeneration period and (iii) thinning intensity.

The felling age is specified at the level of individual major tree species and management units. For the simulated management units, it ranges from 90 to 160 years (Tab. I).

Final felling regime is implemented in the model as a probability depending on felling age and regeneration period (Tab. II). The regeneration period is defined as the time period during which felling of a particular forest stand is completed. This is mostly given by the maximum allowable size of a clear-cut area. These rules are implemented in the model by assigning appropriate probabilities of final felling to different ages. Regeneration periods can range from 20 to 40 years. Generally, beech and oak have the longest rotation period, of about 130-140 years. The regeneration period for oak is 2030 years and for beech $30-40$ years. Pine generally has a felling age of 110-120 years, with 20-30 years regeneration period. Spruce has the shortest rotations with felling age from 90-110 years, and a regeneration period of 20-30 years. However, pine and spruce are also present at unfavorable sites, where the felling age is higher and the regeneration period longer. Distinct regeneration periods are translated as different sets of probabilities in the model (Tab. II).

Thinning intensity was implemented by appropriate coefficients in the model runs (Tab. III). These coefficients were specified on the level of tree species, age class and stand stocking density as defined by the Czech Forestry Act. Thinning was prescribed for forest stands from age of 20 up to 100 years, differentiating stands of major tree species. 
Table III. Thinning (\%) at the level of species, age and stocking as implemented in the model.

\begin{tabular}{|c|c|c|c|c|c|c|c|c|c|c|}
\hline \multirow{2}{*}{ Species } & \multirow{2}{*}{ Relative stocking } & \multicolumn{9}{|c|}{ Age (age class) } \\
\hline & & 20 & 30 & 40 & 50 & 60 & 70 & 80 & 90 & 100 \\
\hline Beech & 7 & & 2 & 1 & 2 & 2 & 2 & 1 & 1 & 1 \\
\hline Beech & 8 & & 10 & 4 & 2 & 2 & 2 & 1 & 1 & 1 \\
\hline Beech & 9 & & 17 & 13 & 10 & 6 & 3 & 1 & 1 & 1 \\
\hline Beech & 10 & & 22 & 21 & 18 & 15 & 13 & 11 & 9 & 8 \\
\hline Beech & 11 & & 28 & 28 & 26 & 23 & 21 & 19 & 17 & 16 \\
\hline Beech & 12 & & 35 & 35 & 33 & 30 & 27 & 26 & 24 & 23 \\
\hline Beech & 13 & & 41 & 41 & 38 & 36 & 33 & 32 & & \\
\hline Beech & 14 & & 46 & 47 & 44 & 41 & & & & \\
\hline Oak & 7 & & 3 & 3 & 3 & 3 & 2 & 2 & 2 & 2 \\
\hline Oak & 8 & & 9 & 3 & 4 & 3 & 2 & 2 & 2 & 2 \\
\hline Oak & 9 & & 18 & 9 & 3 & 3 & 3 & 2 & 2 & 2 \\
\hline Oak & 10 & & 27 & 18 & 12 & 10 & 8 & 6 & 5 & 5 \\
\hline Oak & 11 & & 35 & 26 & 21 & 18 & 16 & 15 & 14 & 13 \\
\hline Oak & 12 & & 43 & 33 & 28 & 25 & 23 & 22 & 21 & 21 \\
\hline Oak & 13 & & 49 & 40 & 35 & 32 & 30 & 29 & & \\
\hline Oak & 14 & & 55 & 45 & 40 & 37 & & & & \\
\hline Pine & 7 & 4 & 4 & 5 & 5 & 4 & 3 & 3 & 3 & 2 \\
\hline Pine & 8 & 7 & 4 & 6 & 5 & 5 & 4 & 3 & 3 & 3 \\
\hline Pine & 9 & 15 & 7 & 7 & 6 & 6 & 5 & 4 & 3 & 3 \\
\hline Pine & 10 & 20 & 15 & 14 & 12 & 11 & 9 & 9 & 8 & 7 \\
\hline Pine & 11 & 26 & 23 & 22 & 21 & 19 & 18 & 17 & 17 & 16 \\
\hline Pine & 12 & 33 & 30 & 30 & 28 & 26 & 25 & 25 & 24 & 23 \\
\hline Pine & 13 & 40 & 37 & 36 & 34 & 33 & 31 & 31 & 30 & \\
\hline Pine & 14 & 46 & 43 & 41 & 40 & 38 & 37 & & & \\
\hline Pine & 15 & 52 & 48 & 46 & 44 & & & & & \\
\hline Spruce & 7 & & 1 & 2 & 2 & 2 & 2 & 2 & 2 & 2 \\
\hline Spruce & 8 & & 2 & 3 & 3 & 3 & 2 & 2 & 2 & 2 \\
\hline Spruce & 9 & & 7 & 4 & 3 & 3 & 3 & 3 & 2 & 2 \\
\hline Spruce & 10 & & 15 & 12 & 11 & 9 & 8 & 7 & 6 & 6 \\
\hline Spruce & 11 & & 22 & 20 & 18 & 17 & 15 & 15 & 14 & 14 \\
\hline Spruce & 12 & & 30 & 27 & 25 & 24 & 22 & 22 & 21 & 21 \\
\hline Spruce & 13 & & 37 & 33 & 31 & 30 & 28 & 28 & 27 & \\
\hline Spruce & 14 & & 42 & 39 & 36 & 35 & 34 & & & \\
\hline Spruce & 15 & & 48 & 43 & 41 & & & & & \\
\hline
\end{tabular}

\subsection{Soil carbon stock calculation (YASSO)}

YASSO applied as a sub-model within EFISCEN calculates the equilibrium of soil carbon status with the imposed climatic conditions and litter input within the first modeling step, which was for the year 2000 in our case. The climatic data needed for YASSO are temperature and moisture deficit. Since the forest stands as used in this study represent a heterogeneous mosaic of actual sites, we applied the country-wide mean annual temperature $\left(7.3^{\circ} \mathrm{C}\right)$ and a mean difference between precipitation and potential evaporation of $-50 \mathrm{~mm}$ during vegetation period (May-September) for all management units.

\subsection{Management and climate scenarios}

Three management scenarios were analyzed in the current study: business as usual (BAU), maximum sustainable (MAX) and multifunctional (MTF). The major criterion for management is the requested harvest level in the simulated period (until 2060). All runs started with the known harvest levels of 2000 and 2005, with actual total harvest of 14.44 and 15.51 million $\mathrm{m}^{3}$ respectively (MA, 2001; 2006). Note that merchantable wood volumes are expressed under bark and include stem and branch wood from reaching at least $7 \mathrm{~cm}$ in diameter. The thinning volumes were always set to $25 \%$ of the total felled volumes, which corresponds to the reported quantities in this country.

The BAU scenario addresses the question of likely development of forest resources under forest management as today. It assumes that the current total felling levels (reporting year 2005) would remain constant during the simulation period. Reported total felling levels were distributed on the basis of the actual share of growing stock volume for coniferous and broadleaved species.

The target of the MAX scenario is to close the gap between increment and felling, indicating the maximum possible harvest under sustainable drain of available wood resources. Under the MAX scenario the felling level is increased by at maximum $10 \%$ per time step (5 years) until the felling level was equal to the increment level.

The MTF scenario involves several aspects of forest management. The scenario prescribes a gradual change of species composition, promoting broadleaved species on account of spruce. This was implemented so that $30 \%$ of the clearcut spruce areas were regenerated with beech and oak, while the proportion of pine remained unchanged. The felling requests in the MTF scenario were set as intermediate between BAU and MAX.

Additionally, the three management scenarios were evaluated also under scenarios of changing climate conditions (CC), abbreviated as BAU_CC, MAX_CC and MTF_CC. Climate change effects on forest growth were taken from a previous modeling effort of the LTEEF and SCEFORMA projects (Kramer and Mohren, 2001; Schelhaas et al., 2004), applying the results of the FORGRO process model (Kramer et al., 2002). The specific increment coefficients changed marginally with tree age; the average increment effect adopted here for broadleaves was 1.069, 1.116 and 1.150 in year 2010, 2030 and 2050, respectively. Correspondingly, the average volume increment effect due to climate change implemented for conifers was 1.107 , 1.196 and 1.252 in year 2010, 2030 and 2050, respectively. The felling levels for MAX and MTF scenarios were adapted to the new conditions. Effects on soil carbon can be included directly via changes in climate parameters. As climate predictions of precipitation amount and distribution patterns remain unsure, we considered two climate change cases: (i) a sole temperature increase (CCT) and (ii) temperature increase combined with increasing moisture deficit (CCTM). The scenario CCT considered a transient change of temperature from today leading to $+3{ }^{\circ} \mathrm{C}$ in 2100 , while the CCTM scenario also included gradual changes of seasonal (May-September) moisture deficit from $50 \mathrm{~mm}$ to $80 \mathrm{~mm}$ during the simulated period.

\subsection{Sensitivity analysis}

Sensitivity analyses have been carried out for EFISCEN (Schelhaas et al., 2007) and YASSO (Liski et al., 2005) separately. The models are coupled via the litter production of EFISCEN. Litter production in EFISCEN depends mainly on the turnover coefficients of each compartment. To complement the existing analyses, we studied the sensitivity of YASSO to changes in these turnover coefficients. For each of the compartments (stem, branches, foliage, coarse roots and fine roots) we varied the turnover coefficient by plus and minus $10 \%$ as compared to the default values. This was done only for the BAU and MAX scenario, both under current and changed climate conditions. 


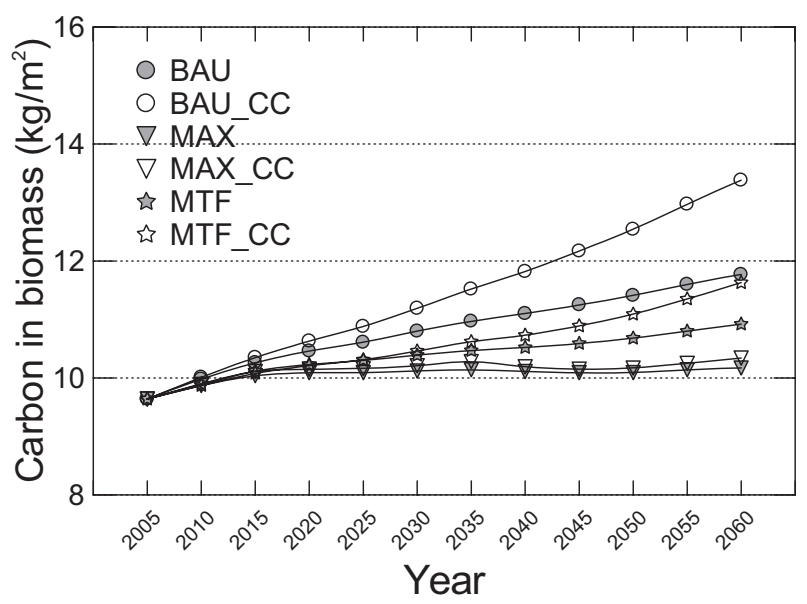

Figure 2. Development of total tree biomass (incl. belowground) until 2060 under different management scenarios (BAU, MAX, MTF), excluding or including the effect of climate change (CC).

\section{RESULTS}

\subsection{Carbon stock in biomass}

The effect of different management scenarios with different harvest levels directly affected the modeled biomass trends (Fig. 2). With respect to the estimated carbon content held in tree biomass in $2005\left(9.64 \mathrm{~kg} / \mathrm{m}^{2}\right.$ and $7.35 \mathrm{~kg} / \mathrm{m}^{2}$ including and excluding belowground components, respectively), the biomass pool increased for all tested scenarios for the simulated period. The largest effect was observed for the BAU scenario that conserves the current felling level for the whole simulated period. Under the BAU scenario, carbon pool of tree biomass would increase by $22 \%$ by 2060 . This increase would be larger under the imposed conditions of environmental changes, namely by $39 \%$ with respect to the reference year of 2005. On the contrary, the biomass pool would increase only slightly within next 10 to 15 years and then remain basically unchanged under the MAX scenario (Fig. 2), which attempts to maximize felling approaching the limit given by the level of the mean current increment. Under the MAX scenario, biomass pool would reach about 10.2 and $10.3 \mathrm{~kg} \mathrm{C} / \mathrm{m}^{2}$ in 2060, which represents 5 and $7 \%$ increase for the conditions of the current and changing environmental conditions, respectively. Finally, under the MTF scenario, which prescribes an intermediate harvest increase and promotes planting of broadleaved species on account of conifers, the carbon pool held in biomass would increase by 13 and $21 \%$ relative to the baseline (BAU scenario) for the current and changing climatic conditions, respectively.

A similar trend was observed for the growing stock volumes (figure not shown). With respect to the reference quantity $268 \mathrm{~m}^{3} /$ ha (merchantable volume under bark) reported for 2005 (MA, 2006), the mean growing stock would increase to $326 \mathrm{~m}^{3} / \mathrm{ha}$ in 2060 under the current harvest level (BAU scenario). Considering additionally the effect of environmental change, the simulated mean growing stock would reach

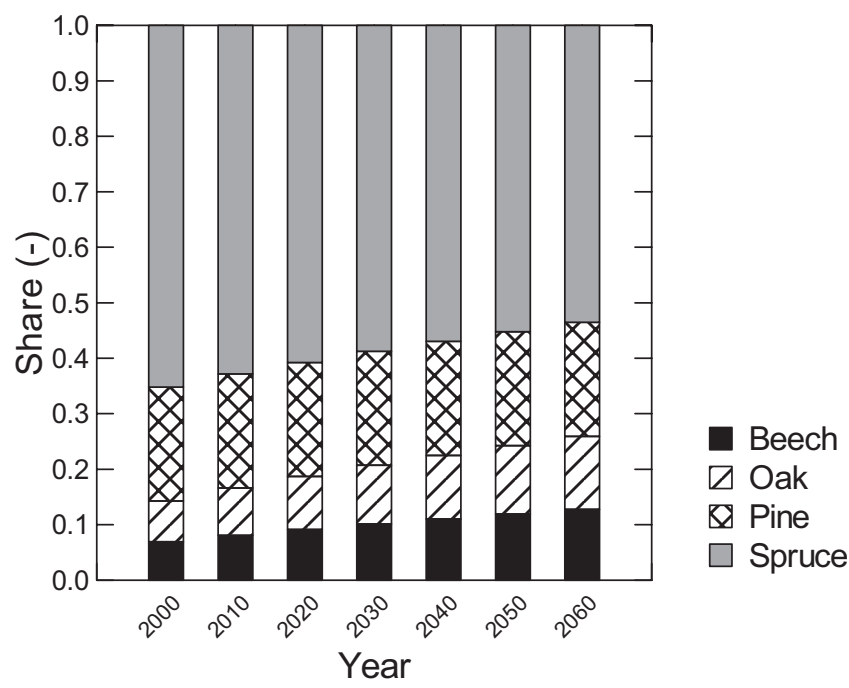

Figure 3. The change of species composition under MTF scenario for the simulated period. Note that the share of spruce declined to $53.5 \%$ in 2060 from over $65 \%$ in 2000 , while the share of broadleaved increased from about $14 \%$ in 2000 to $26 \%$ in 2060.

$371 \mathrm{~m}^{3} / \mathrm{h}$. This represents an increase of 21 and $38 \%$, respectively, relative to the year 2005. With the maximum harvest levels balancing the increment (MAX scenario), the mean growing stock would stabilize at 5 to $6 \%$ above the level observed in 2005. Adopting moderate increase of felling levels and changes to species composition under the MTF scenario, the mean growing stock would increase by $10 \%$ under current environmental conditions, or by $18 \%$ considering the likely changes in environmental conditions. Since the biomass pool is basically derived from the volume data of growing stock, the relative trends in growing stock match well those of biomass described above. A more pronounced difference is observed for the MTF scenario, which reflects the effect of changing proportions of broadleaved and coniferous species prescribed there (Fig. 3).

Regarding the expected harvest levels, the EFISCEN simulations indicated that the maximum attainable annual harvest that would not decrease growing stock levels (MAX scenario) could reach values from 16.9 and $19.710^{6} \mathrm{~m}^{3}$ (merchantable volume under bark) in 2060. That range is given by either omitting or considering the effect of changing conditions to growth. Under the more moderate harvest in the MTF scenario, the corresponding harvest levels would reach 16.1 and $17.410^{6} \mathrm{~m}^{3}$ annually by 2060 . The ratio of harvest to increment, which indicates the level of sustainable utilization of wood resources, stabilized at about 0.87 and 0.95 for the BAU and MTF scenarios, respectively (Fig. 4). For the conditions of environmental change, the ratio between harvest and increment decreased to 0.72 (BAU) and 0.84 (MTF) in 2060, reflecting a considerably larger build-up of wood resources and biomass in forests. Under the MAX scenario, harvest was adjusted so as to balance increment, hence the ratio of harvest to increment always approached 1.0 (Fig. 4). 


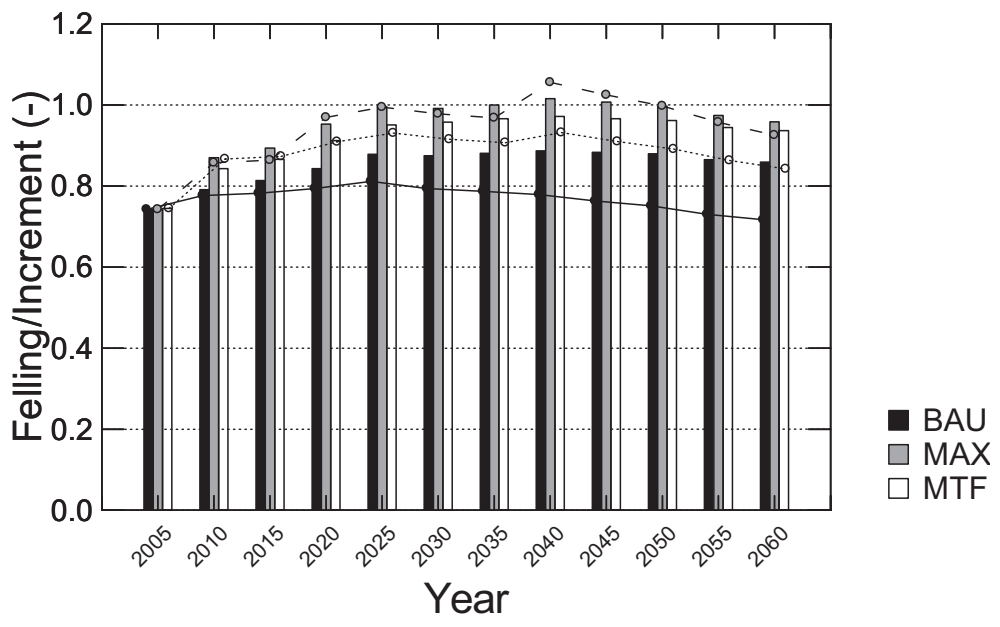

Figure 4. The ratio of felling to increment for particular scenarios BAU, MAX and MTF. The lines with symbols show the ratios with imposed climate change conditions for BAU (solid line), MAX (dashed line) and MTF (dotted line) scenarios.

\subsection{Carbon stock in soil}

The mean carbon stock of the forest soils in the Czech Republic as estimated by the model reached $7.84 \mathrm{~kg} / \mathrm{m}^{2}$ in 2005 . It generally increased under all management scenarios, but the rate and responses differed during the simulated period (Fig. 5). Soil response to different management regimes was detectable early, however, larger differences were observed only after three or more decades. In the long-term, the largest build-up of soil carbon was observed for the BAU scenario, which conserves the harvest levels at those of 2005 and results in increasing growing stock. Under the BAU scenario, the mean soil carbon stock would reach $8.37 \mathrm{~kg} / \mathrm{m}^{2}$ in 2060 , an increase of about $0.5 \mathrm{~kg} \mathrm{C} / \mathrm{m}^{2}$ or about $6.8 \%$ relative to year 2005. Under the MAX scenario, soil carbon initially increased, but remained rather stable at the level between 8.10 to $8.15 \mathrm{~kg} \mathrm{C} / \mathrm{m}^{2}$ from 2040 to 2060 . This is an increase by $4 \%$ relative to the conditions simulated in 2005. A rather large build-up of carbon was observed under the MTF scenario with $8.31 \mathrm{~kg} \mathrm{C} / \mathrm{m}^{2}$ observed for year 2060 . This is an increase by $0.47 \mathrm{~kg} / \mathrm{m}^{2}$, or about $6 \%$ relative to year 2005 .

An increased temperature (CCT) resulted in decreased accumulation rate for all management scenarios. This effect was largest for the MAX and MTF scenarios: it would reduce soil carbon stock by 0.20 and $0.11 \mathrm{~kg} / \mathrm{m}^{2}$ in 2060 , respectively, or $1.3 \%$ compared to the levels attained without the temperature effect. On the other hand, the reduced moisture availability stimulated soil carbon accumulation for all management scenarios. Considering the joint effect of temperature and moisture deficit (CCTM, Fig. 5) under BAU would give the mean carbon stock of $8.49 \mathrm{~kg} / \mathrm{m}^{2}$ in 2060 , which is about $8.3 \%$ above the reference level in 2005. For the MAX and MTF scenarios, the effect of CCTM would basically offset the effect of sole temperature increase (CCT). Hence, the accumulation of soil carbon for MAX and MTF under CCTM would be similar to that under current climatic conditions (Fig. 5).

A change in the turnover coefficients of the different biomass compartments had a small effect on the simulated soil

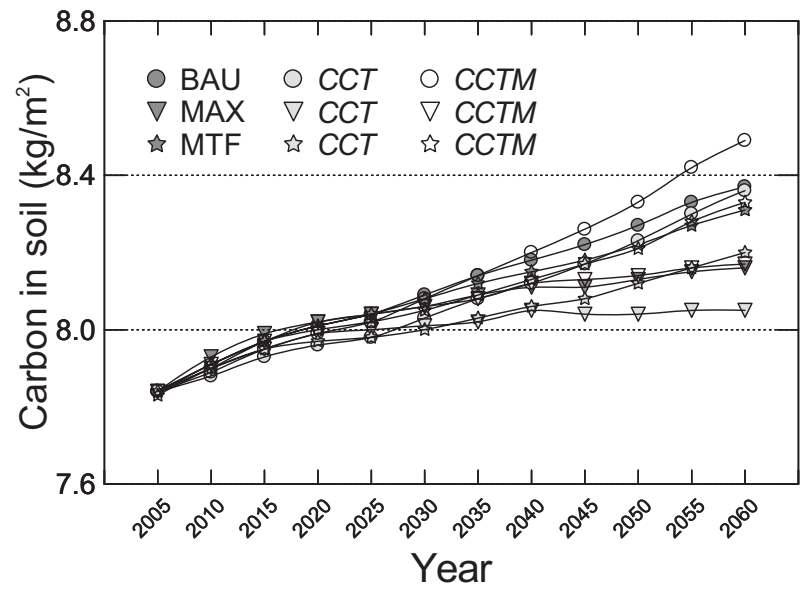

Figure 5. Mean forest soil carbon stock development as simulated by YASSO/EFISCEN for BAU, MAX and MTF scenario; each of these management scenarios is also combined with changing temperature (CCT) and changing temperature with increasing moisture deficit (CCTM).

carbon amounts. Effects ranged from a $0.87 \%$ change in soil carbon for a $10 \%$ change in branch turnover to a $2.17 \%$ change in soil carbon for a $10 \%$ change in fine root turnover (Tab. IV). Changing the turnover parameters resulted in a linear shift of the soil carbon curves up- or downwards (Fig. 6).

\section{DISCUSSION}

\subsection{Biomass}

Forest management is the decisive factor affecting carbon balance in managed forests (Kauppi et al., 1992). The differences in the requested harvest levels by the particular management scenarios determine different build-up of carbon stock 


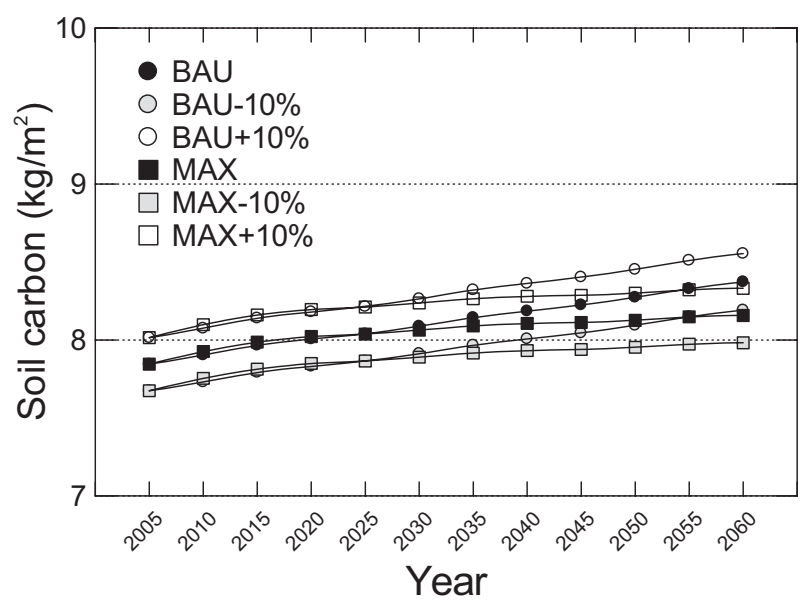

Figure 6. Sensitivity of soil carbon stock to changes in fine-root turnover parameter, evaluated for the BAU and MAX management scenarios and current climate conditions. In both cases, root turnover parameter is either increased or decreased by $10 \%$ from the default values.

held in biomass. The biggest increase in biomass carbon pool was observed for the BAU scenario, for which would the biomass carbon stock (incl. roots) approach $12 \mathrm{~kg} / \mathrm{m}^{2}$ by the end of the simulated period. Due to a rather short simulation period (until 2060), it was not possible to assess the limits of biomass accumulation or build up of growing stock. Even stronger increase of forest biomass carbon pool was predicted once the expected increase in current increment was included, which would give a mean carbon stock (incl. roots) around $13 \mathrm{~kg} / \mathrm{m}^{2}$. Such values would correspond to a growing stock (merchantable wood volume) of about $370 \mathrm{~m}^{3} / \mathrm{ha}$. Such values are reported from some European regions, such as those in Switzerland (Rihm, 2007). In the conditions of the Czech Republic, such levels of growing stock might be theoretically attainable, although in practice, one may expect an increasing impact of large-scale disturbances and decreased stability of forest stands once the mean stand age would be further increasing. These factors would hamper the overall forest biomass carbon stock accumulation. On the other hand, rather high mean values of carbon stock held in forest biomass were already reported for Belgium, reaching $10.1 \mathrm{~kg} \mathrm{C} / \mathrm{m}^{2}$ and for Germany with about $10.6 \mathrm{~kg} \mathrm{C} / \mathrm{m}^{2}$ (Vande Walle et al., 2005). The disturbance effects mentioned above were not included in the current runs, although a newer, adapted EFISCEN application permits this already (e.g. Schelhaas, 2008; Schelhaas et al., 2002).

It should be noted, however, that the model implementation of climate change effects remains very simplistic. Specifically, the increased growing stock means an increased foliage mass or leaf area index, which is commonly not the case. The model does not allow implementation of functional responses related to growing stock volume. Instead, the control of biomass allocation remains secured by age-dependent, species-specific factors (Tab. III). While this mechanism prevents unrealistic
Table IV. The effected of increased $(+10 \%)$ and decreased $(-10 \%)$ value of fine root turnover parameter on modeled soil carbon stock in 2050, exemplified on BAU and MAX management scenarios. The results are expressed as changes in \% with respect to the simulated soil carbon stock using default parameter value.

\begin{tabular}{lcccc}
\hline Scenarios & \multicolumn{2}{c}{ BAU } & \multicolumn{2}{c}{ MAX } \\
\hline Parameter change & $+10 \%$ & $10 \%$ & $+10 \%$ & $-10 \%$ \\
\hline Stem & 1.82 & 1.81 & 1.74 & 1.74 \\
Branches & 0.87 & 0.87 & 0.85 & 0.85 \\
Coarse roots & 1.06 & 1.06 & 1.03 & 1.03 \\
Fine roots & 2.17 & 2.17 & 2.14 & 2.14 \\
Foliage & 1.37 & 1.36 & 1.36 & 1.36 \\
\hline
\end{tabular}

values of foliage mass to be accumulated, this issue should be included in the list of further model improvements.

The species composition changes defined under the MTF scenario evoked a reduction of areas with spruce stands and an increase of areas with deciduous species (beech and oak). This trend is supported in the Czech Republic, where an increase of ecological stability of forests, biodiversity and share of structurally rich forests should all be prioritized in the conditions of the country. It is vital to recognize that this change in species composition may result in a small decline in growing stock volume, but that would be fully compensated in terms of woody biomass and carbon stock. This is due to a higher wood density of broadleaved species $\left(0.58 \mathrm{t} / \mathrm{m}^{3}\right)$ as compared to spruce $\left(0.40 \mathrm{t} / \mathrm{m}^{3}\right)$, the currently dominating tree species in the country.

\subsection{Soil}

The most important observations sought by this study were the trends in soil carbon content under likely management and climate scenarios. It has been shown that neither of the applied scenarios or their combination resulted in a mean carbon loss from forest soils in the foreseeable future. This confirms the analysis of (Liski et al., 2005), who estimated development of soil carbon budget for 16 European countries. This study did not elaborate on the effect on climate change drivers, but concluded that the carbon sink in forest soils (in Western Europe) will be more affected by management actions in existing forests rather than by afforestation. In the conditions of managed forest in Europe, forest soil is reported to accumulate (not loose) carbon provided the forest stands are managed in a sustainable manner, i.e., preventing mean growing stock to decrease (e.g. Liski et al, 2006). This is a commonly adopted practice in European countries, which does not allow harvest to exceed the current increment. There are two major factors affecting the trends in soil carbon accumulation: (i) litter input to the soils and (ii) climatic conditions (temperature and precipitation). While the litter input is linked to the amount of tree biomass stock, climatic factors affect the rates of decomposition. Hence, increasing biomass stock results in larger litter input from living trees and increasing soil carbon stock. It should be noted, however, that such model implementation of stand development remains rather simplistic and the model 
should be refined to reflect the possibly changing proportion of biomass components with climate change and age. This is an issue of concern specifically for older stands and high growing stock volumes and should be a focus of further model improvement.

On the contrary to increasing growing stock, the effect of climatic drivers is nonlinear and may jointly be either increasing or decreasing carbon accumulation in this compartment. Both moisture availability and temperature are critically important for decomposition and respiration processes and the likely change in environmental conditions may significantly affect emissions of $\mathrm{CO}_{2}$ from this carbon pool.

In the conception of the YASSO model, soil carbon represents both organic and mineral soil horizons and individual attribution of processes to these horizons is not possible. This is a weakness of the model, since mineral and organic parts may behave differently as some studies show (e.g. Morari et al., 2006). On the other hand, such situations may be expected only for soils under changing land use, such as conversion of cropland or grassland to forest land. For the category of forest land remaining forest land, which was the subject of our study, consistent trends in organic and mineral soil horizons should be expected.

The quantitative estimations of soil carbon stock by YASSO matched the empirical observations made for comparable conditions elsewhere. In a study evaluating soil sampling in Western Bohemia, (Cienciala et al., 2006) estimated the mean forest soil carbon stock for the depth of $30 \mathrm{~cm}$ as $9.3 \mathrm{~kg} \mathrm{C} / \mathrm{m}^{2}$. The reference values observed for forest soil in Switzerland, which covered subalpine and alpine regions, reached $9.7 \mathrm{~kg}$ $\mathrm{C} / \mathrm{m}^{2}$ (Thürig, 2005). Based on an extensive forest soil sampling in Belgium, (Lettens et al., 2005) reported the mean soil carbon stock in the upper $30 \mathrm{~cm}$ as $8.7,9.2$ and $9.3 \mathrm{~kg} / \mathrm{m}^{2}$ for broadleaved, coniferous and mixed forest stands, respectively. Soil carbon stock from a chronosequence study in Uppland, Sweden, for the mixed forests (Scots pine and Norway spruce) was reported to be $8.5 \mathrm{~kg} \mathrm{C} / \mathrm{m}^{2}$ in 35 -year stand, $6.5 \mathrm{~kg} \mathrm{C} / \mathrm{m}^{2}$ in 65-year stand and $8.8 \mathrm{~kg} \mathrm{C} / \mathrm{m}^{2}$ in 103-year stand (Lagergren et al., 2006). Other observations on mineral soil carbon content were reported by Cerli et al. (2006) from SW Sweden, ranging from 8.0 to $9.6 \mathrm{~kg} / \mathrm{m}^{2}$. This was also similar to the estimated soil carbon pools in the American NE temperate deciduous forests (Curtis et al., 2002).

Determination and simulation of soil carbon are surrounded with uncertainties. Uncertainty estimates are needed not only for the purpose of the emission inventory of the LULUCF sector, but also for more sound evaluation of the observed trends and effects of climate and management scenarios. Soil carbon is fed by litter input. The amount of litter depends on the size of the biomass compartments and its turnover parameters. The size of the biomass compartments scales linearly with the simulated growing stock volume in EFISCEN via the biomass expansion factors. Similarly, as shown by the sensitivity analysis (Tab. IV), the turnover parameters have a linear effect on simulated soil carbon stocks. Uncertainties in either expansion factors or turnover coefficients will thus only change the absolute level of the simulated soil carbon stocks, but not the trends. The dynamics of soil carbon within YASSO are de- termined by its internal parameters. In an uncertainty analysis using the Monte-Carlo approach, Liski et al. (2005) concluded that the parameters concerning the humus compartments were most uncertain and most influential. However, these parameters largely determine the absolute level of soil carbon, but do not influence the trends. Therefore, they concluded that "YASSO's estimates for annual changes in soil carbon, which are induced by changes in litter production, are more reliable than the estimates for the amount of soil carbon". A similar observation was made by Peltoniemi et al. (2006), who addressed uncertainty of modeled soil carbon stock of YASSO using a Monte-Carlo analysis.

The model evidence of trends in soil carbon stock under the tested set of sustainable forest management scenarios and constraints of practical forest management in the country should meet the basic reporting requirements of emission inventory from forests under the UNFCCC and its Kyoto protocol (IPCC, 2003). These permit omitting a carbon pool from reporting once it can be justified that it is not a source of emissions. However, for key categories (i.e., those important by quantity or trend within other emission categories of a country), more rigorous quantitative estimates will be required. This, in turn, calls for a thorough estimation of associate uncertainties. Fortunately, a new version of the YASSO model including uncertainty estimates is under development (J. Liski, pers. comm. 2007). Combined with rigorous estimates of uncertainties associated with biomass estimates (e. g., Lehtonen et al., 2007), this would give more credibility in quantitative analysis of carbon stock development in managed European forest ecosystems.

To conclude, this model application represents a practicable country-level analysis of carbon stock changes in biomass and soil compartments under a defined set of management and climate scenarios. Using the actual data of forest biomass, growth performance and growing conditions, the analysis shows that under the adopted sustainable forest management practices implemented in the country, one may consider that forest soil carbon pool does not decrease (loose carbon), i.e., it is not a net source of emissions. In the situation of inadequate soil sampling for a rigorous statistical estimation based on repeated country-level soil inventory campaigns, still rather common situation in Europe (Cienciala et al., 2008b), such analysis and results can serve as an argument for omitting soil and litter carbon pools from (otherwise obligatory) reporting emissions related to the activity of Forest management, Art. 3.4 of the Kyoto protocol. Additional effort is needed for estimating the associated uncertainty, which will be addressed once the new YASSO model version will be released.

Acknowledgements: This study was supported by the Czech Ministry of Environment (Project CzechCARBO - VaV/640/18/03). We thank Ari Pussinen for his helpful comments to the manuscript.

\section{REFERENCES}

Cerli C., Celi L., Johansson M.-B., Kogel-Knabner I., Rosenquist L., and Zanini E., 2006. Soil organic matter changes in a spruce 
chronosequence on Swedish former agricultural soil: I. Carbon and lignin dynamics. Soil Sci. 171: 837-849.

Cerny M., 2005. Use of the growth models of main tree species of the Czech Republic in combination with the data of the Czech National Forest Inventory. In: Neuhöferová P. (Ed.), The growth functions in forestry, Korf's growth function and its use in forestry and world reputation, Kostelec nad Èernými lesy, Prague, Czech University of Agriculture Prague, ISBN 80-213-1331-5 (in Czech).

Cienciala E., Apltauer J., Cerny M., and Exnerova Z., 2005. Biomass functions applicable for European beech, J. For. Sci. (Prague) 51: 147-154.

Cienciala E., Exnerova Z., Macku J., and Henzlik V., 2006. Forest topsoil organic carbon content in Southwest Bohemia region. J. For. Sci. (Prague) 52: 387-398.

Cienciala E., Cerny M., Tatarinov F., Apltauer A., and Exnerova Z., 2006. Biomass functions applicable to Scots pine. Trees 20: 483-495.

Cienciala E., Apltauer J., Exnerova Z., and Tatarinov F., 2008a. Biomass functions applicable to oak trees grown in Central-European forestry. J. For. Sci. (Prague) 54: 109-120.

Cienciala E., Tomppo E., Snorrason A., Broadmeadow M., Colin A., Dungler K., Exnerova Z., Lassere B., Petersson H., Priwitzer T., Sanchez Pena G., and Stahl G., 2008b. Preparing reporting systems for LULUCF: use of National Forest Inventories in European countries. Silva Fenn. 42: 73-88.

Curtis P.S., Hanson P.J., Bolstad P., Barford C., Randolph J.C., Schmid H.P., and Wilson K.B., 2002. Biometric and eddy-covariance based estimates of annual carbon storage in five eastern North American deciduous forests. Agric. For. Meteorol. 113: 3-19.

IPCC, 2003. Good Practice Guidance for Land Use, Land-Use Change and Forestry, Institute for Global Environmental Strategies (IGES), Hayama, Japan, ISBN 4-88788-003-0.

Kaipainen T., Liski J., Pussinen A., and Karjalainen T., 2004. Managing carbon sinks by changing rotation length in European forests. Environ. Sci. Pollut. 7: 205-219.

Kauppi P.E., Mielikainen K., and Kuusela K., 1992. Biomass and carbon budget of European forests, 1971 to 1990. Science 256: 70-74.

Kramer K. and Mohren G.M.J., 2001. Long-term effects of climate change on carbon budgets of forests in Europe, Final Report of LTEEF II. Report 194, Alterra, Wageningen.

Kramer K., Leinonen I., Bartelink H.H., Berbigier P., Borghetti M., Bernhofer C., Cienciala E., Dolman A.J., Froer O., Gracia C.A., Granier A., Grunwald T., Hari P., Jans W., Kellomaki S., Loustau D., Magnani F., Markkanen T., Matteucci G., Mohren G.M.J., Moors E., Nissinen A., Peltola H., Sabate S., Sanchez A., Sontag M., Valentini R., and Vesala T., 2002. Evaluation of six process-based forest growth models using eddy-covariance measurements of $\mathrm{CO}_{2}$ and $\mathrm{H}_{2} \mathrm{O}$ fluxes at six forest sites in Europe. Glob. Change Biol. 8: 213-230.

Lagergren F., Grelle A., Lankreijer H., Molder M., and Lindroth A., 2006. Current carbon balance of the forested area in sweden and its sensitivity to global change as simulated by Biome-BGC. Ecosystems 9: 894-908

Lehtonen A., Cienciala E., Tatarinov F., and Makipaa R., 2007. Uncertainty estimation of biomass expansion factors for Norway spruce in the Czech Republic. Ann. For. Sci. 64: 133-140.

Lettens S., Orshoven J., Wesemael B., Muys B., and Perrin D., 2005. Soil organic carbon changes in landscape units of Belgium between 1960 and 2000 with reference to 1990. Glob. Change Biol. 11: 2128-2140.

Liski J., Lehtonen A., Palosuo T., Peltoniemi M., Eggers T., Muukkonen P., and Makipaa R., 2006. Carbon accumulation in Finland's forests 1922-2004 - an estimate obtained by combination of forest inventory data with modelling of biomass, litter and soil. Ann. For. Sci. 63: 687-697.

Liski J., Palosuo T., Peltoniemi M., and Sievanen R., 2005. Carbon and decomposition model Yasso for forest soils. Ecol. Model. 189: 168182.

MA, 2001. Report on Forestry of the Czech Republic by December 31, 2000. Published by the Czech Ministry of Agriculture (in Czech).

MA, 2006. Report on the State of Forests and Forestry in the Czech Republic by 2005. Published by the Czech Ministry of Agriculture (in Czech).
Morari F., Lugato E., Berti A., and Giardini L., 2006. Long-term effects of recommended management practices on soil carbon changes and sequestration in north-eastern Italy. Soil Use Manage. 22: 71-81.

Muukkonen P., 2005. Needle litter production rates of Scots pine (Pinus sylvestris L.) derived from the needle-shed dynamics. Trees Struct. Funct. 19: 273-279.

Muukkonen P. and Lehtonen A., 2006. Needle and branch biomass turnover rates of Norway spruce (Picea abies). Can. J. For. Res. 3: 2517-2527.

Nabuurs G.-J., Paivinen R., and Schanz H., 2001. Sustainable management regimes for Europe's forests - a projection with EFISCEN till 2050. For. Pol. Econ. 3: 155-173.

Nabuurs G.-J., Pussinen A., Karjalainen T., Erhard M., and Kramer K., 2002. Stemwood volume increment changes in European forests due to climate change - a simulation study with the EFISCEN model. Glob. Change Biol. 8: 1-13.

Palosuo T., Liski J., Trofymow J.A., and Titus B.D., 2005. Litter decomposition affected by climate and litter quality - Testing the Yasso model with litterbag data from the Canadian intersite decomposition experiment. Ecol. Model. 189: 183-198.

Peltoniemi M., Palosuo T., Monni S., and Makipaa R. 2006. Factors affecting the uncertainty of sinks and stocks of carbon in Finnish forests soils and vegetation. For. Ecol. Manage. 232: 75-85.

Plíva K., 1991. Funkene integrovane lesni hospodarstvi, UHUL, Brandys n. Labem.

Plíva K. and Zlábek I., 1986. Prirodni lesni oblasti CSR, Czech Ministry of Forest and Water Management, SZN, Prague, $316 \mathrm{p}$.

Pussinen A., Schelhaas M.J., Verkaik E., Heikkinen E., Liski J., Karjalainen T., Paivinen R., and Naaburs G.J., 2001. Manual for the European Forest Information Scenario Model (EFISCEN 2.0). EFI Internal Report No. 5.

Sallnas O., 1990. A matrix growth model of the Swedish forest. Studia Forestalia Suecica No. 183, Swedish Univ. Agr. Sci, Faculty of Forestry, Uppsala, $23 \mathrm{p}$.

Schelhaas M.J., 2008. Impacts of natural disturbances on the development of European forest resources: application of model approaches from tree and stand levels to large-scale scenarios. Dissertationes Forestales 56, Alterra Scientific Contributions 23.

Schelhaas M.-J., Nabuurs G.J., Sonntag M., and Pussinen A., 2002. Adding natural disturbances to a large-scale forest scenario model and a case study for Switzerland. For. Ecol. Manage. 167: 13-26.

Schelhaas M.J., Cerny M., Buksha I.F., Cienciala E., Csoka P., Karjalainen T., Kolozs L., Nabuurs G.J., Pasternak V., Pussinen A., Sodor M., and Wawrzoniak J., 2004. Scenarios on forest management in Czech Republic, Hungary, Poland and Ukraine, European Forest Institute Research Report 17, Brill, Leiden, Boston, Köln.

Schelhaas M.J., van Brusselen J., Pussinen A., Pesonen E., Schuck A., Nabuurs G.J., and Sasse V., 2006. Outlook for the Development of European Forest Resources. A study prepared for the European Forest Sector Outlook Study (EFSOS), Geneva Timber and Forest Discussion Paper, ECE/TIM/DP/41, UN-ECE, Geneva, 118 p.

Rihm B., 2007. Switzerland's Greenhouse Gas Inventory 1990-2005, National Inventory Report 2007, Land Use, Land-Use Change and Forestry. Federal Office of the Environment FOEN, 292 p.

Thürig E., 2005. Carbon budget of Swiss forests: evaluation and application of empirical models for assessing future management impacts, A dissertation No. 15872 submitted to the Swiss Federal Institute of Technology Zurich (ETHZ).

Thürig E. and Schelhaas M.-J., 2006. Evaluation of a large-scale forest scenario model in heterogenous forests: a case study for Switzerland, Can. J. For. Res. 36: 671-683.

Vande Walle I., Van Camp N., Perrin D., Lemeur R., Verheyen K., Van Wesemael B., and Laitat E., 2005. Growing stock-based assessment of the carbon sock in the Belgian forest biomass. Ann. For. Sci. 62: 853-864.

Wirth C., Schumacher J., and Schulze E.-D., 2004. Generic biomass functions for Norway spruce in Central Europe - a-meta-analysis approach toward prediction and uncertainty estimation. Tree Physiol. 24: 121-139. 